\title{
Consolidation of the new nuclear calculation methodology of the IEA-Rl reactor
}

\author{
Giovanni Laranjo de Stefani ${ }^{1,2}$; Thadeu das Neves Conti ${ }^{2}$ \\ \giovanni_laranjo@yahoo.com.br
}

1. Universidade Federal do ABC, Avenida dos Estados, 5001, Santo André, Brasil.

2. IPEN/USP Instituto de Pesquisas Energéticas e Nucleares, Avenida Lineu Prestes, 2242, São Paulo, Brasil.

\section{Article History:}

Received: August 10, 2017

Accept: September 19, 2017

Published: January 5, 2018

\begin{abstract}
The IEA-R1 neutron and thermo-hydraulic calculation methodology is composed of 5 computational codes from the area of reactor physics, which have a symbiotic dependence on each other. Since the outputs of each code will be used to generate the input of the next code. The programs involved in this methodology are LEOPARD, HAMMER-TECHNION, TWODB, CITATION and COBRA. Each of these codes is responsible for a specific type of calculation. In a first two-year study, between the years 2008 and 2010, these IEA-R1 nuclear reactor codes were integrated into a single management code. This management code had as main objective the reduction of the time spent by the calculation team of the reactor and to prevent against errors in the manipulation of data and data output. In this study the calculation time was reduced by $99 \%$. The present article presents the closing of this work, being a document with the consolidation of 7 years of the use of the new calculation methodology implemented in the IEA-R1 reactor, demonstrating its efficiency and reliability, besides the proper registration of this project that had great importance Within the IPEN research reactor.
\end{abstract}

Keywords: IEA-R1, Nuclear Reactor, CITATION, COBRA, TWODB.

\section{Consolidação da nova metodologia de cálculo nuclear do reator IEA-R1}

Resumo: A metodologia de cálculos neutronicos e termo hidráulicos do reator IEA-Rl é composta de 5 códigos computacionais da área de física de reatores, que possuem uma dependência simbiótica entre si. Sendo que as saídas de cada código são utilizadas para gerar a entrada do próximo código. Os programas envolvidos nesta metodologia são o LEOPARD, HAMMER-TECHNION, TWODB, CITATION e COBRA. Cada um destes códigos é responsável por um tipo específico de cálculo. Em um primeiro estudo de dois anos de duração, entre os anos de 2008 e 2010, esses códigos nucleares do reator IEA-R1 foram integrados em um único código gerenciador. Esse código gerenciador teve como principal objetivo a redução do tempo gasto pela equipe de cálculo do reator e prevenir contra erros na manipulação de dados das saídas de dados. Neste estudo o tempo de cálculo foi reduzido em $99 \%$. 0 presente artigo apresenta o fechamento deste trabalho, sendo um documento com a consolidação de 7 anos da utilização da nova metodologia de cálculo implementada no reator IEA-Rl, demonstrando sua eficiência e confiabilidade, além do registro de forma adequada deste projeto que possuiu grande importância dentro do reator de pesquisas do IPEN.

Palavras-chave: IEA-RI, Reator Nuclear, CITATION, COBRA, TWODB. 


\title{
Consolidación de la nueva metodología de cálculo nuclear del reactor IEA-Rl
}

\begin{abstract}
Resumen: La metodología de cálculos neutrones y termo hidráulicos del reactor IEA-R1 se compone de 5 códigos computacionales del área de física de reactores, que poseen una dependencia simbiótica entre sí. Dado que las salidas de cada código se utilizarán para generar la entrada del código siguiente. Los programas involucrados en esta metodología son LEOPARD, HAMMER-TECHNION, TWODB, CITATION y COBRA. Cada uno de estos códigos es responsable de un tipo específico de cálculo. En un primer estudio de dos años de duración, entre los años 2008 y 2010, estos códigos nucleares del reactor IEA-Rl se integraron en un único código gestor. Este código gestor tuvo como principal objetivo la reducción del tiempo empleado por el equipo de cálculo del reactor y prevenir contra errores en la manipulación de datos de las salidas de datos. En este estudio el tiempo de cálculo se redujo en un 99\%. El presente artículo presenta el cierre de este trabajo, siendo un documento con la consolidación de 7 años de la utilización de la nueva metodología de cálculo implementada en el reactor IEA-Rl, demostrando su eficiencia y confiabilidad, además del registro de forma adecuada de este proyecto que posee gran importancia Dentro del reactor de investigación del IPEN.
\end{abstract}

Palabras clave: IEA-R1, Reactor nuclear, CITATION, COBRA, TWODB.

\section{INTRODUCTION}

The safety analysis of nuclear reactors to predict the behavior of the system, under normal and extreme conditions, is performed through computational codes as can be seen in the works of Maiorino et al. (2017) and Monteiro et al. (2018).In this way the codes for reactor analysis need to be validated continuously to demonstrate their reliability. The results of modeling performed with nuclear codes also need to be compared with experimental data to ensure their reliability, whether by the operation of the code itself or by its nuclear libraries.

The codes used to predict the behavior of nuclear reactors are generally divided into two distinct areas: neutronics and termohydraulics. Neutronics is the area of reactor physics that describes the behavior of neutrons in the reactor, and their codes can be deterministic or stochastic.

The deterministic codessuch as those developed by Delp et al. (1964), Bencik et al. (2002), Greenman et al. (1979) and Joo et al. (2002) they mostly use the neutron diffusion equation, being an approximation of the transport equation. The codes that use diffusion equation show some approximations of model and even limitations, but are advantageous with respect to the speed at which the calculations are realized.

The stochastic codes, based on the Monte Carlo method such as those developed by Dunn and Shultis (2002), Leppänen et al. (2015) and Booth (2014) present as advantages a 
better description of the problem. However, they are programs that have a very high computational cost, demanding a dedicated cluster.

The Reactor Research Center (CRPq) located in IPEN does not have a dedicated cluster for this procedure, so there is a preference for codes that can be used on a conventional computer. The codes used, although not recent, present reliable results to the process. These codes are used to predict the behavior of the IEA-Rl reactor.

The IEA-Rl reactor is the oldest nuclear research reactor in Latin America. This reactor was built and designed by the American company Babcock \& Wilcox in 1956 and was critical for the first time in 1957 according to what is quoted on the IPEN website (2017). The creation of the project came from the North American initiative called "Atoms for Peace", then President Dwight Eisenhower. The program proposed the creation of the International Atomic Energy Agency, linked to the UN and cooperation for the training of technicians and research institutions, as long as they are geared towards civilian uses. The civil uses foresee applications in medicine, agriculture and of course electricity generation. The reactor operated at $1 \mathrm{MW}$ in the early years, and its power was increased to $2 \mathrm{MW}$ between 1960 and 1995 for 8 hours daily, 5 days a week. After a series of upgrades, the reactor began operating for 64 hours per week at a power ranging from 2.5 to 3.5 MW according to Maiorino (1999), and on its 40th anniversary in 1997 the reactor reached its maximum power at $5 \mathrm{MW}$ recorded in a CNEN report (2014). Since then it has been operated at $4.5 \mathrm{MW}$ for 62 hours per week according to Cárdenas' thesis (2000).

The IEA-R1 reactor is used for various purposes, but also for a very large number of users in practice is that its configuration, its configuration is different. This configuration change in the reactor core is calculated based on a methodology developed by the division of reactor physics at the Center for Nuclear Engineering. Several programs perform these calculations. Each of the programs uses different input files. Where these data inputs are interdependent, the output of each program provides data that will be used in the input of the next program. The objective of this work was to make this interdependence automatic. Making the process automatic and preventing errors in manual manipulation of data. This article proposes a validation of the methodology developed. Through comparisons with operational data such as those previously reported to FAPESP by Stefani and Conti (2009 and 2010), a 
journal of nuclear engineering by Stefani and Conti (2010) and a conference by Laranjo et al. (2011).

\section{Original Calculation Methodology}

The neutronic calculation methodology from the Reactors Physics Division is based on the following programs: LEOPARD developed by Barry (1963) and TECHNION-HAMMER developed by Barhen, Rhotenstein and Taviv (1978) for cross sections generation, TWODB developed by Little and Hardie(1969) to calculate the core and fuel combustion in two dimensions and CITATION developed by Fowler, Vondy and Cunnigham (1972) to calculate the core in three dimensions. The HAMMER performs multigroup cellular analysis, with the neutron gauge considering the asymptotic reactor model through buckling, used as input parameter.

The cross-sections are extremely important factor in the reactor physics, they will tell you how likely a nuclear reaction will be. Whether this reaction of fission, capture or scattering for example. These are the most important data within a reactor calculation and should be continuously updated with experimental data generated by large research laboratories such as Los Alamos National Lab (LANL), Laboratory National Henri Becquerel (LNHB), among others. Thus each laboratory has its library of cross-sections.

From the cross-section data that will feed the TWODB inputs and the geometry provided the reactor behavior will be evaluated with TWODB and CITATION. In these calculations the neutron flux across the reactor can be determined, this factor contributes both to the power and to the rate of nuclear reactions, since the product between the cross sections and the neutron flux will provide the reaction per unit of time. In these calculations it is possible to determine the time that a nuclear fuel will take until it is exhausted or even how exhausted it will be in a given interval of time. Other factors such as cut-off margin and effectiveness of control banks will also be determined with these programs.

One of the major limiters within a nuclear reactor is the melting temperature of the constituent elements, so COBRA will have the function of saying the maximum temperature reached in the hot channel. This is in the fuel that has higher temperature. The hot channel is 
directly connected to the fuel with higher neutron flux in the reactor and is dependent on the data provided by the CITATION code.

\section{Neutronic Calculations}

Figure 1 from the Yamaguchi's report(1997) below illustrates a flow chart of the calculations used on the neutron part. The LEOPARD program uses the supercell model homogenizing the fuel, cladding and moderator for calculating the impact section. The cross sections are generated for 30 days of operation of the reactor, with as a parameter reaching $50 \%$ of fission uranium firing $\left({ }^{235} \mathrm{U}\right)$. This information generated by LEOPARD is used by the LINS program that converts the file into a format suitable for the TWODB code.

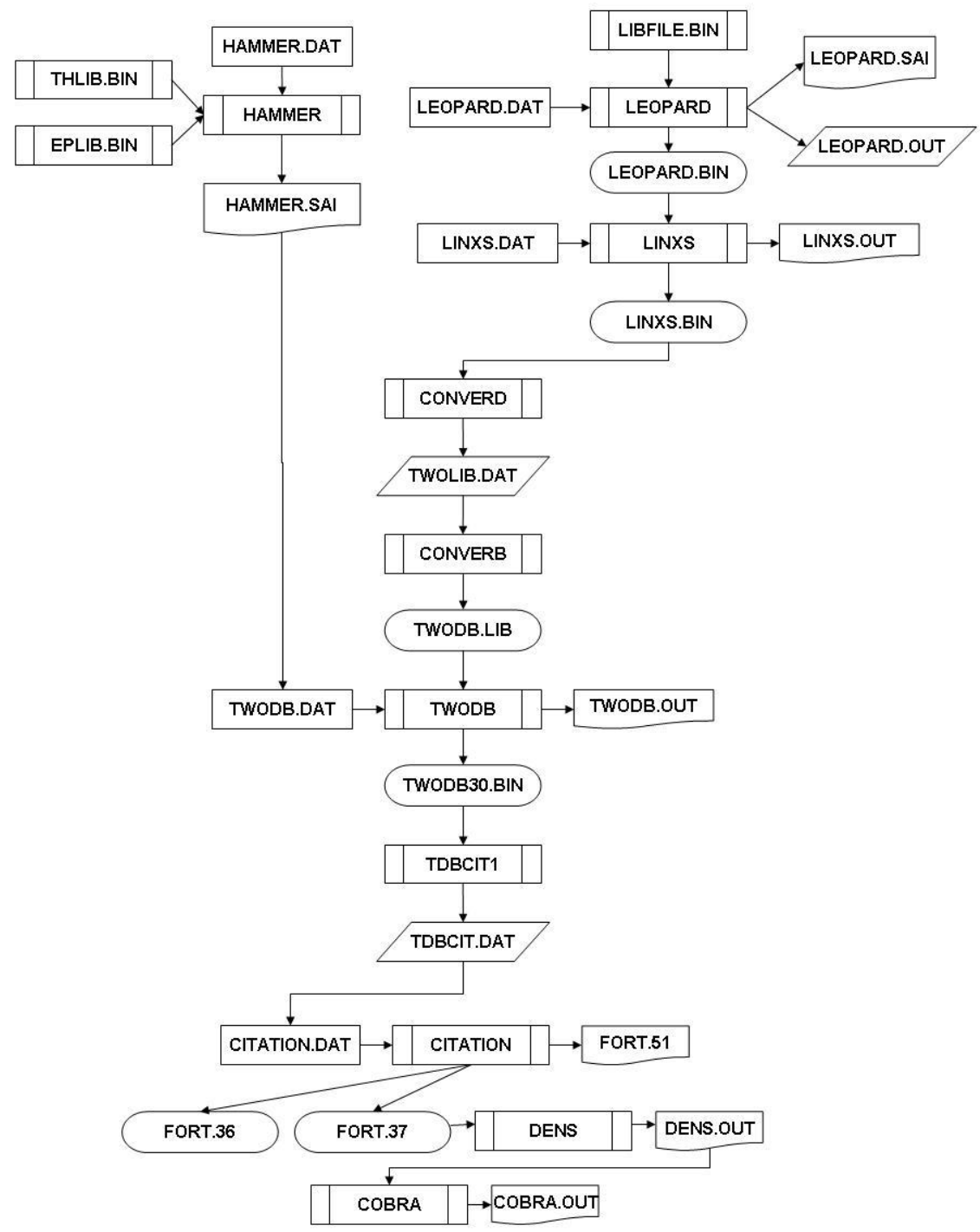

Figure 1. Flowchart of Neutronic Calculations

Source: Yamaguchi's Report (1997). 
For the cross sections of materials without fuel, the applied methodology involves the program HAMMER-Technion, instead of LEOPARD. The rest of the process is similar to that applied to the LEOPARD code described above.

The behavior of the reactor is thus simulated by the TWODB code, in two dimensions and without control bars inserted. In this model, factors such as effective multiplication factor, fissile material consumption, neutron flux, and power density are estimated. Changes in the impact sections of the materials due to reactor operation are also estimated.

From the parameters estimated by the TWODB, the data obtained are used by the CITATION program, which has a three-dimensional model, necessary to evaluate the insertion of the control banks in the core. The control bar has the function of being used for power maneuvers, control and shutdown of the reactor. The effective multiplication factor is also estimated for the three-dimensional model, based on the previously generated cross sections. From the three-dimensional study with the CITATION code it is possible to estimate the maximum neutron flux as well as the maximum power density associated with it.

The last program used in this methodology is COBRA. COBRA uses the maximum power density data to calculate hot runner temperatures, ensuring the integrity of the fuel cladding and even the fuel itself. Since both the cladding and the fuel cannot reach the melting temperature.

\section{Effective Kinetic Parameters - Theoretical foundations}

The kinetic parameters of the reactor will assure some operating factors, ensuring the intrinsic safety of the core. These parameters will be:

I) The fraction of prompt neutrons;

II) The coefficient of reactivity of temperature;

III) The fraction of delayed neutrons.

The prompt neutrons will be connected to gamma ray emission, and their knowledge is important in terms of shielding and safety during operation. 
The coefficient of temperature reactivity is diffused in two different coefficients, one being associated to the fuel and the other associated to the moderator (water). These coefficients must always be negative to prevent thermal feedback, ie in case of a temperature increase the reactor becomes more reactive.

The delayed neutrons in turn are linked to the amount of reactivity that can be provided by the control banks, without the reactor reaching the state known as promptcritical, where the generation time of neutrons are so fast that the reactor goes out of control and the core is fully molten.

\section{Emission of neutron in fission}

Nuclear fission is characterized by the emission of neutrons and gamma rays during the process, in addition to the fission of the nucleus in two that will result in the formation of fission products according to Lamarsh (1972).

The neutrons emitted in the process of nuclear fission are classified into two types: the ready neutrons, which are those emitted at the exact moment of nuclear fission and represent 99\% of the neutrons emitted; and delayed neutrons, which are those emitted by the decay of the fission products during their transmutation to another more stable element.

Although the delayed neutrons correspond to less than $1 \%$ of the total neutrons emitted by the system, they play a fundamental role in the control of a thermal reactor. This is due to the fact that its emission is in the order of a few seconds, against microseconds of the generation of the ready neutrons. Thus, the limitation for the safe control of a reactor is the growth of the population of ready neutrons, representing one of the essential kinetic parameters during the power maneuvers of the nucleus.

\section{Methodology for calculating the reactor temperature coefficient}

Nuclear reactors must be designed to prevent them from being feedback during the power increase, i.e. their reactivity (related to the effective multiplication factor) increases during the process. This parameter is known as the temperature reactivity coefficient and 
should be studied for both the fuel and moderator cases. Thusthe effects of temperature changes are the dominant resonance absorption (Dopller effect) due to changes infuel and energy spectrum of neutrons caused by changes in the density of the moderator. Thus this coefficient called temperature coefficient $\alpha_{T}$ depends on the variation of the reactor reactivity ( $\rho$ )and temperature (T) variation (equation 1$)$.

$$
\alpha_{T}=\frac{d \rho}{d T}
$$

In this way the calculation of the reactor temperature coefficient is based on the TECHNION-HAMMER program, which will generate the cross sections, the TWODB code that will determine the transmutation of the fuel over time, in two dimensions, with the bars off, and the CITATION program, which in this case works in two dimensions. The only concern in this case is the variation of the effective multiplication factor $(\mathrm{k})$ that will be used to determine the reactivity according to equation 2 :

$$
=-1
$$

The reactivity is usually given in pcm, which is a unit to measure when $\mathrm{k}$ moves away from 1, given by the result of equation (2) multiplied by one hundred thousand. The temperature reactivity coefficient for both the fuel and the moderator given by equation (1) must be a negative number, ensuring the prevention of reactor feedback with increasing power. Figure 2 from the Yamaguchi's report (1997) shows the diagram of this calculation. 


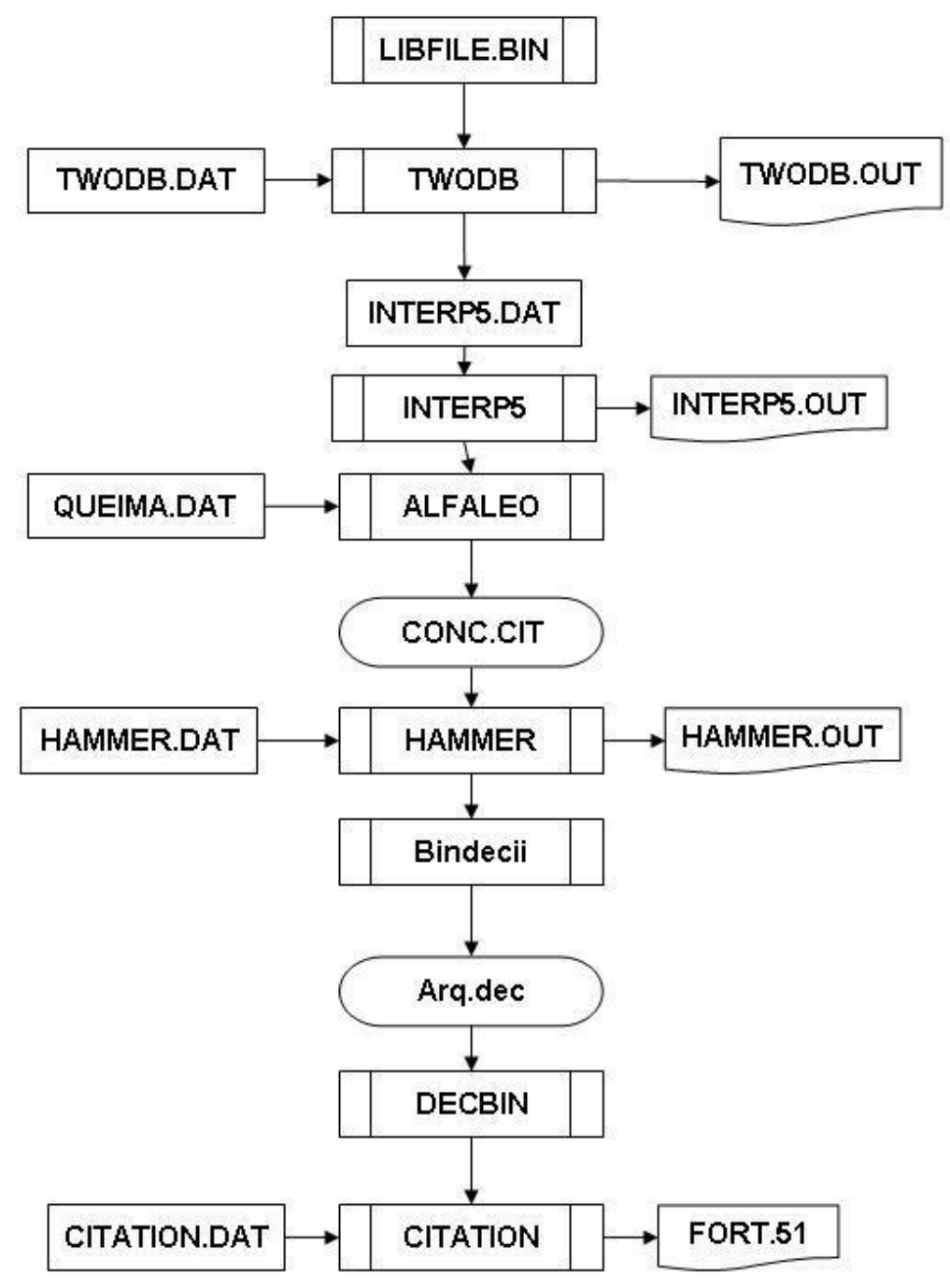

Figure 2: Diagram of the temperature reactivity coefficient calculations. Source: Yamaguchi's Report (1997).

\section{Methodology for delayed neutrons calculation}

The methodology for calculating delayed neutrons is also based on the TechnionHAMMER, TWODB and CITATION programs. In the case of delayed neutrons the calculations will estimate the fraction of ready and delayed neutrons in the neutron population of the reactor during its operation without control banks. The fraction of delayed neutrons will determine which positive reactivity value can be inserted at most during power maneuvers. Figure 3 from the Yamaguchi's report (1997) shows the diagram of this calculation. 


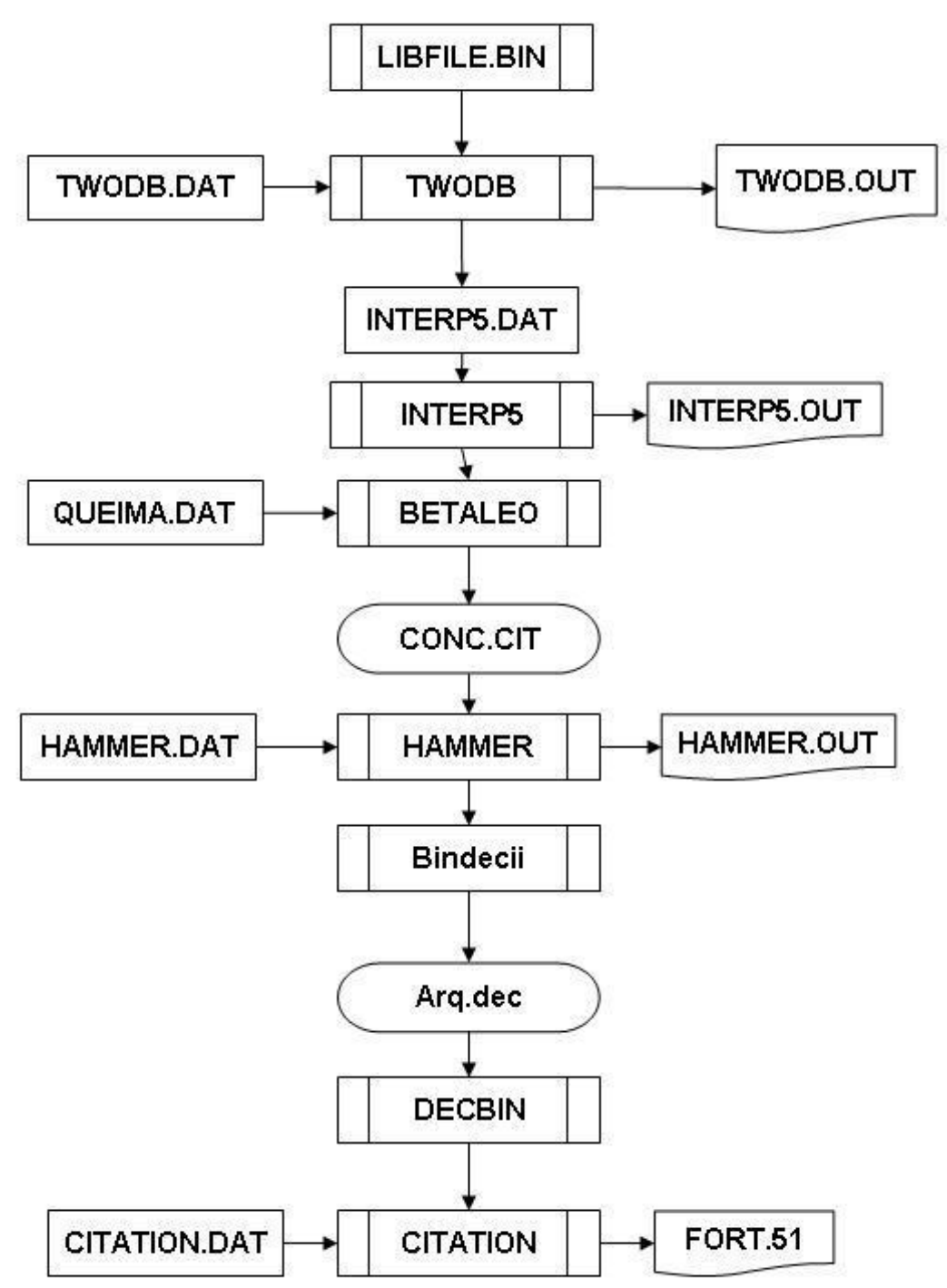

Figure 3. Calculation of delayed neutrons

Source: Yamaguchi's Report (1997).

\section{METHODOLOGY}

In a brief way the methodology of this work was carried out in two parts. In the first part of the study, the codes used to determine the parameters were transformed into subroutines of a main program. In this way it would be possible to call the programs in a single program, without having to execute several programs. In the second part we made coupling programs that would read the file generated by each of the codes involved, extracting in this way the essential information so that the next code could operate. The 
program would also assemble the data input used by the following code, without the need for human intervention, thus streamlining the process.

Thus the new flowchart for reactor simulation becomes as shown below (the new programs are seen in red), in Figure 4 and Figure 5:

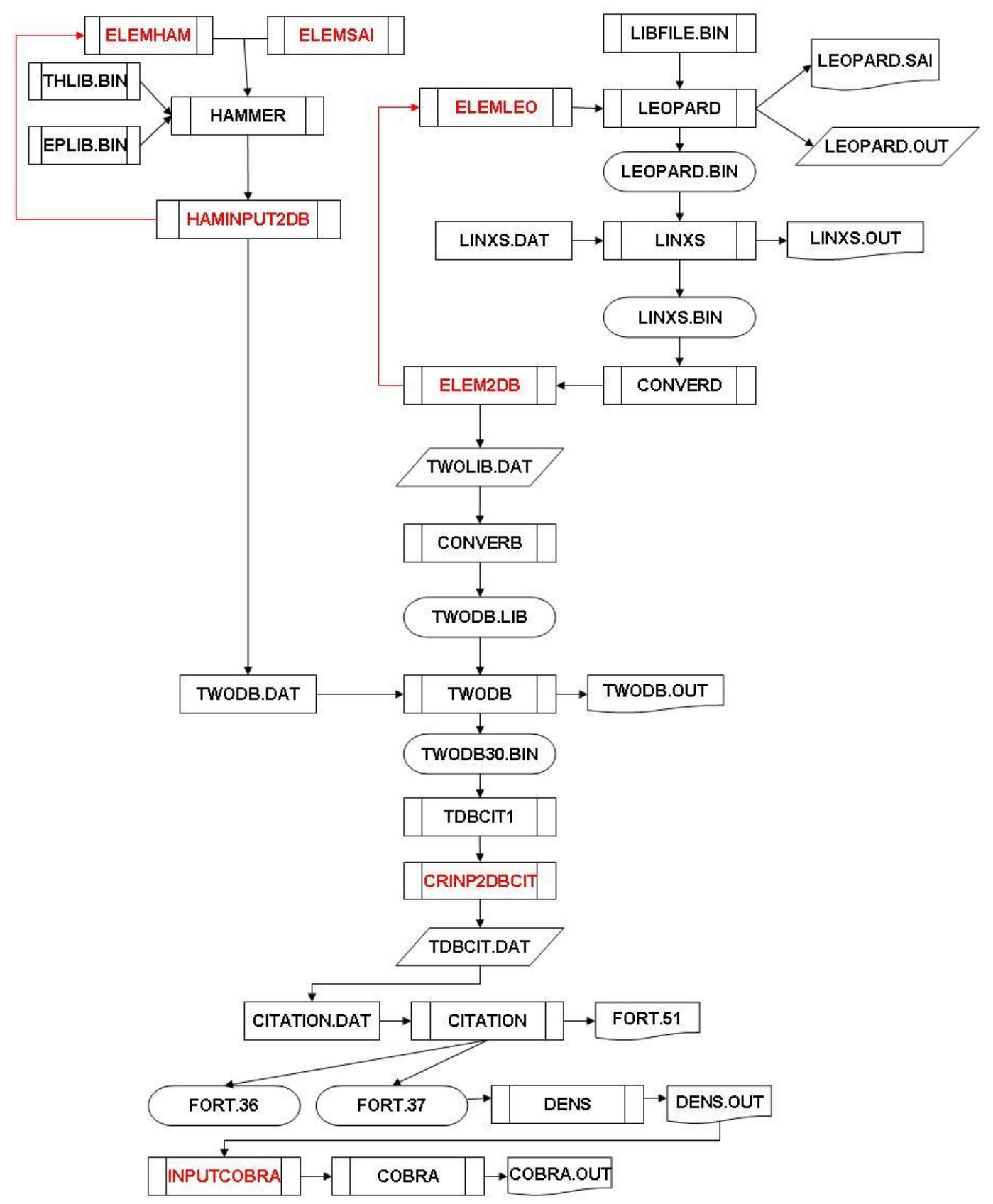

Figure 4. New flowchart for neutronic calculation

Source: Stefani et al. (2011) paper conference. 


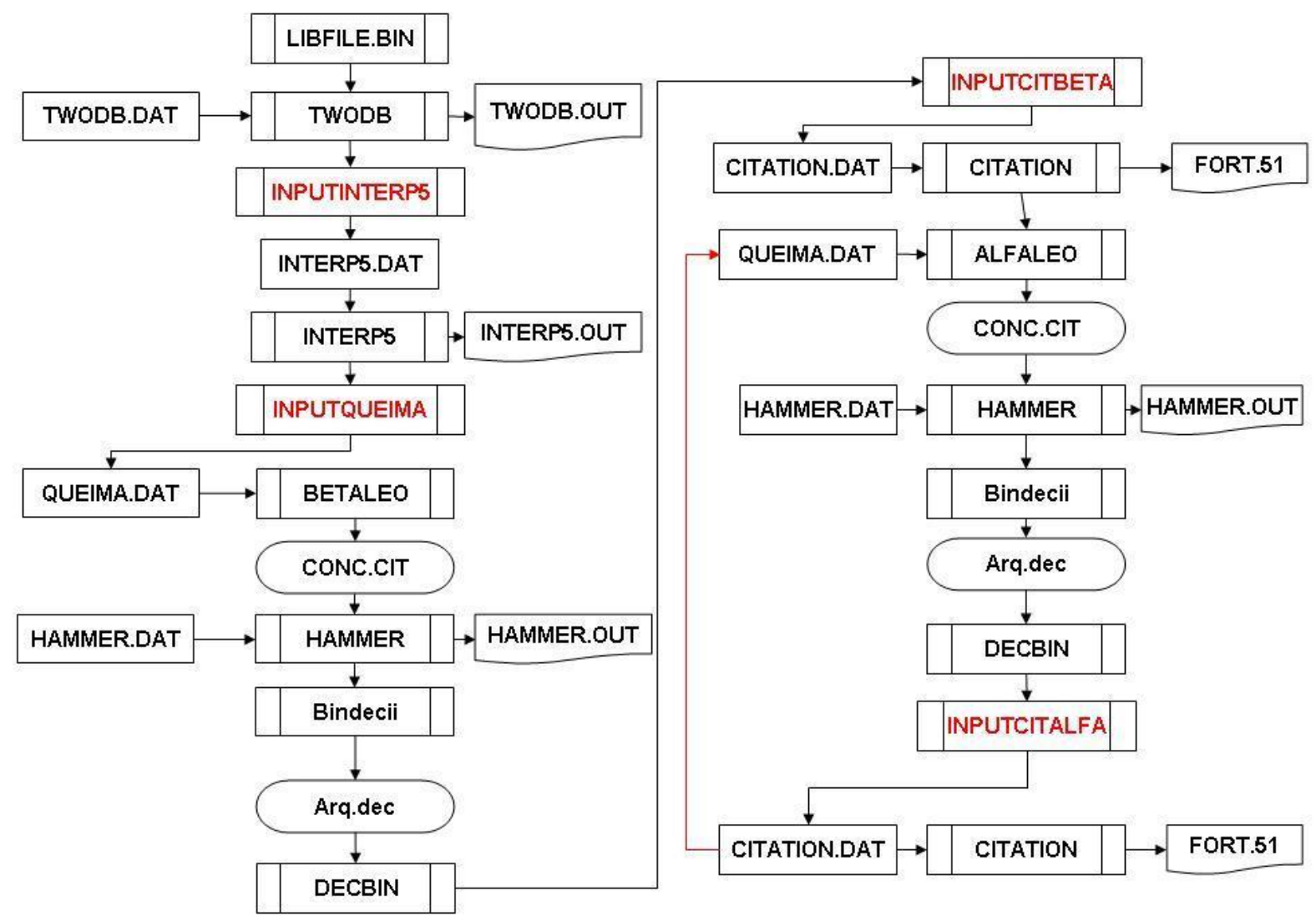

Figure 5. New Flowchart for kinetic parameters

Source: Stefani et al. (2011) paper conference.

The efficiency of the new developed method was determined in a comparison between the results of the new methodology and the old one. The results presented should be identical, since the equations for determining the parameters of the programs were not altered.

\section{RESULTS}

The effective multiplication factor of the reactor is associated with the increase of neutrons with each new generation, being associated in this way with the adequate control of the reactor. During the operation of a nuclear reactor the change of this value will be determinant for maintenance, decrease or increase of the power, being that for the reactor to be able to reach its criticality it must be bigger than one during the beginning of the 
operation. The change in the multiplication factor is due to two factors. The first one occurs due to the use of the fuel and the second due to the insertion of control banks.

The temperature in the cladding of the fuel is decisive to guarantee its integrity, since the thermal limits must be respected in order to prevent against the melting point. In the case of IEA-R1 the temperature in the claddingis of far more fundamental importance than in the fuel, since the melting temperature of the claddingis much lower than that of the material used in the fuel. Its thermal limit is that of aluminum (368.15 K or $\left.203^{\circ} \mathrm{F}\right)$.

In the second part of the work the fraction of delayed neutrons and the coefficient of temperature reactivity were calculated. The calculations were made using the old calculation methodology and the new methodology proposed by this paper.

The fraction of delayed neutrons will be associated with the maximum amount of reactivity that can be inserted into the nucleus, without being jeopardized, entering the prompt criticality state. In nuclear engineering, prompt criticality is said to be reached during a nuclear fission event if one or more of the immediate or prompt neutrons released by an atom in the event causes an additional fission event resulting in a rapid, exponential increase in the number of fission events. Prompt criticality is a special case of supercriticality. In this process, the following parameters are calculated: the delayed neutron fraction yield in each precursor group and its decay rate, where the effective neutron fraction $\left(\beta_{\mathrm{ef}}\right)$ is the sum of the delayed neutron fraction precursors $\left(\beta_{\mathrm{i}}\right)$ in all groups. The decay rate is related to the average concentration of each precursor group. In this methodology the time of generation ofprompt neutrons $\Lambda(\mu \mathrm{s})$ also calculated. The results were obtained for two different configurations and present complete agreement, being presented in tables 1 and 2. 
Table 1 - Kinetic parameters for the configuration 258 of the IEA-R1 Reactor - 28/09/2016

\begin{tabular}{ccccc}
\hline Precursor Group & $\begin{array}{c}\text { Delayed Neutron fraction } \\
\text { precursor yield }\left(\boldsymbol{\beta}_{\mathrm{i}}\right)^{\mathbf{1}}\end{array}$ & $\begin{array}{c}\text { Delayed Neutron fraction } \\
\text { precursor yield }\left(\boldsymbol{\beta}_{\mathrm{i}}\right)^{2}\end{array}$ & $\begin{array}{c}\text { Decay rate } \\
\boldsymbol{\lambda}_{\mathrm{i}}\left(\mathbf{s}^{-1}\right)^{\mathbf{1}}\end{array}$ & $\begin{array}{c}\text { Decay rate } \\
\boldsymbol{\lambda}_{\mathrm{i}}\left(\mathbf{s}^{-1}\right)^{2}\end{array}$ \\
\hline 1 & $2.86541 \mathrm{E}-04$ & $2.86541 \mathrm{E}-04$ & 0.01272 & 0.01272 \\
2 & $1.56115 \mathrm{E}-03$ & $1.56115 \mathrm{E}-03$ & 0.03174 & 0.03174 \\
3 & $1.42417 \mathrm{E}-03$ & $1.42417 \mathrm{E}-03$ & 0.11600 & 0.11600 \\
4 & $3.07276 \mathrm{E}-03$ & $3.07276 \mathrm{E}-03$ & 0.31100 & 0.31100 \\
5 & $9.74879 \mathrm{E}-04$ & $9.74879 \mathrm{E}-04$ & 1.40000 & 1.40000 \\
6 & $2.01709 \mathrm{E}-04$ & $2.01709 \mathrm{E}-04$ & 3.87000 & 3.87000 \\
\hline Effective neutron & $7.52121 \mathrm{E}-03$ & $7.52121 \mathrm{E}-03$ & & \\
fraction $\left(\boldsymbol{\beta}_{\mathrm{ef}}\right)$ & & & & \\
Time of generation of & $7.44267 \mathrm{E}-05$ & $7.44267 \mathrm{E}-05$ & & \\
steady neutrons $\boldsymbol{\Lambda}(\boldsymbol{\mu} \mathrm{s})$ & & & &
\end{tabular}

1 - Calculated using the old methodology;

2 - Calculated using the new methodology.

Source: Author.

Table 2 - Parameters for the configuration 259 of the IEA-R1 Reactor - 18/04/2017

\begin{tabular}{ccccc}
\hline Precursor Group & $\begin{array}{c}\text { Neutron precursor } \\
\text { yield }\left(\boldsymbol{\beta}_{\mathrm{i}}\right)^{\mathbf{1}}\end{array}$ & $\begin{array}{c}\text { Neutron precursor } \\
\text { yield }\left(\boldsymbol{\beta}_{\mathrm{i}}\right)^{2}\end{array}$ & $\begin{array}{c}\text { Decay rate } \\
\boldsymbol{\lambda}_{\mathbf{i}}\left(\mathbf{s}^{-1}\right)^{\mathbf{1}}\end{array}$ & $\begin{array}{c}\text { Decay rate } \\
\boldsymbol{\lambda}_{\mathbf{i}}\left(\mathbf{s}^{-1}\right)^{\mathbf{2}}\end{array}$ \\
\hline 1 & $2.86777 \mathrm{E}-04$ & $2.86777 \mathrm{E}-04$ & 0.01272 & 0.01272 \\
2 & $1.56213 \mathrm{E}-03$ & $1.56213 \mathrm{E}-03$ & 0.03174 & 0.03174 \\
3 & $1.42523 \mathrm{E}-03$ & $1.42523 \mathrm{E}-03$ & 0.11600 & 0.11600 \\
4 & $3.07529 \mathrm{E}-03$ & $3.07529 \mathrm{E}-03$ & 0.31100 & 0.31100 \\
5 & $9.75650 \mathrm{E}-04$ & $9.75650 \mathrm{E}-04$ & 1.4000 & 1.4000 \\
6 & $2.01845 \mathrm{E}-04$ & $2.01845 \mathrm{E}-04$ & 3.8700 & 3.8700 \\
\hline $\begin{array}{r}\text { Effective neutron } \\
\text { fraction }\left(\boldsymbol{\beta}_{\mathrm{ef}}\right)\end{array}$ & $7.52692 \mathrm{E}-03$ & & & \\
Time of generation of & $7.39214 \mathrm{E}-05$ & & & \\
steady neutrons $\boldsymbol{\Lambda}(\boldsymbol{\mu} \mathbf{s})$ & & & & \\
\hline
\end{tabular}

1 - Calculated using the old methodology

2 - Calculated using the new methodology

Source: Author

Tables 3 and 4 present the results for the temperature reactivity coefficients, an important safety parameter that must be checked after each new configuration. The reactivity coefficient of temperature must always be negative, that means, a positive temperature variation causes a decrease in reactor power. This parameter prevents reactivity from 
increasing and, therefore, the reactor will not go out of control. It is estimated by the difference in reactivity between these two states, divided by the temperature variation in these two states. The calculations were performed for two different configurations of the reactor to ensure that the methodology is fully functional.

Table 3 - Reactivity's Coefficient for the configuration 258 of theIEA-R1 Reactor - 28/09/2016

\begin{tabular}{cccccc}
\hline $\begin{array}{c}\text { Moderator } \\
\begin{array}{c}\text { Temperature } \\
\text { Range } \\
\left({ }^{\circ} \mathrm{C}\right)\end{array}\end{array}$ & $\begin{array}{c}\text { Fuel } \\
\text { Temperature } \\
\text { Range } \\
\left({ }^{\circ} \mathrm{C}\right)\end{array}$ & $\begin{array}{c}\text { Fuel } \\
\text { reactivity's } \\
\text { coefficient }^{1} \\
\left(\mathbf{p c m} /{ }^{\circ} \mathrm{C}\right)\end{array}$ & $\begin{array}{c}\text { Fuel } \\
\text { reactivity's } \\
\text { coefficient }^{2} \\
\left(\mathbf{p c m} /{ }^{\circ} \mathrm{C}\right)\end{array}$ & $\begin{array}{c}\text { Moderator } \\
\text { reactivity's } \\
\text { coefficient }^{1} \\
\left(\mathbf{p c m} /{ }^{\circ} \mathrm{C}\right)\end{array}$ & $\begin{array}{c}\text { Moderator } \\
\text { reactivity's }^{\mathbf{c o e f f i c i e n t}^{2}} \\
\left(\mathbf{p c m} /{ }^{\circ} \mathrm{C}\right)\end{array}$ \\
\hline 80 & $20-50$ & -1.99786 & -1.99786 & - & - \\
80 & $50-100$ & -1.89441 & -1.89441 & - & - \\
80 & $100-200$ & -1.70867 & -1.70867 & - & - \\
$20-40$ & 80 & - & - & -5.65513 & -5.65513 \\
$40-60$ & 80 & - & - & -8.65283 & -8.65283 \\
$60-80$ & 80 & - & - & -11.1012 & -11.1012 \\
\hline
\end{tabular}

1 - Calculated using the old methodology

2 - Calculated using the new methodology

Source: Author

Table 4 - Reactivity's Coefficient for the configuration 259 of theIEA-R1 Reactor - 18/04/2017

\begin{tabular}{|c|c|c|c|c|c|}
\hline $\begin{array}{c}\text { Moderator } \\
\text { Temperature } \\
\text { Range } \\
\left({ }^{\circ} \mathrm{C}\right)\end{array}$ & $\begin{array}{c}\text { Fuel } \\
\text { Temperature } \\
\text { Range } \\
\left({ }^{\circ} \mathrm{C}\right)\end{array}$ & $\begin{array}{c}\text { Fuel } \\
\text { reactivity's } \\
\text { coefficient }^{1} \\
\left(\mathrm{pcm} /{ }^{\circ} \mathrm{C}\right)\end{array}$ & $\begin{array}{c}\text { Fuel } \\
\text { reactivity's } \\
\text { coefficient }^{2} \\
\left(\mathrm{pcm} /{ }^{\circ} \mathrm{C}\right)\end{array}$ & $\begin{array}{l}\text { Moderator } \\
\text { reactivity's } \\
\text { coefficient } \\
\left(\mathrm{pcm} /{ }^{\circ} \mathrm{C}\right)\end{array}$ & $\begin{array}{c}\text { Moderator } \\
\text { reactivity's } \\
\text { coefficient }^{2} \\
\left(\mathrm{pcm} /{ }^{\circ} \mathrm{C}\right)\end{array}$ \\
\hline 80 & $20-50$ & -1.9931688 & -1.9931688 & - & - \\
\hline 80 & $50-100$ & -1.8904891 & -1.8904891 & - & - \\
\hline 80 & $100-200$ & -1.7050830 & -1.7050830 & - & - \\
\hline $20-40$ & 80 & - & - & -5.691215 & -5.691215 \\
\hline $40-60$ & 80 & - & - & -8.703621 & -8.703621 \\
\hline $60-80$ & 80 & - & - & -11.165699 & -11.165699 \\
\hline
\end{tabular}

1 - Calculated using the old methodology

2 - Calculated using the new methodology

Source: Author 
Finally, for the adequate closure of this study, for the purpose of determining the validation of the code in the 7 years of study, it was taken comparative data between the old and the new methodology between 2011 and 2017. The values taken for comparison were the effective multiplication factor (K), Maximum temperature in the fuel cladding (T), moderator temperature reactivity coefficient $\left(\alpha_{M}\right)$ and fuel temperature reactivity coefficient $\left(\alpha_{F}\right)$, and effective delayed neutrons fraction $\left(\beta_{\mathrm{ef}}\right)$.These values are presented in table 5 below, where each configuration (conf.) and date is described.

Table 5 -Comparison between data generated by the old and new methodology between 2011 and 2017

\begin{tabular}{|c|c|c|c|c|c|c|c|c|c|c|c|}
\hline \multirow{2}{*}{$\begin{array}{l}\text { Conf. } \\
243 \mathrm{~A}\end{array}$} & \multirow{2}{*}{$\begin{array}{c}\text { Date } \\
04 / 2010\end{array}$} & \multirow{2}{*}{$\begin{array}{c}\mathbf{K}^{\mathbf{1}} \\
1.06085\end{array}$} & \multirow{2}{*}{$\begin{array}{c}\mathrm{K}^{2} \\
1.06085\end{array}$} & \multirow[b]{2}{*}{99} & $\mathrm{~T}^{2}$ & \multicolumn{2}{|c|}{$\beta_{\mathrm{ef}}^{1}{ }_{\mathrm{xl} .0 \mathrm{E}-03}{ }^{\beta_{\mathrm{ef}}^{2}}$} & \multicolumn{3}{|c|}{$\alpha_{\left(\mathrm{pcm} /{ }^{\circ} \mathrm{C}\right)}^{\alpha_{\mathrm{F}}^{1}}$} & \multirow{2}{*}{$\begin{array}{c}\boldsymbol{\alpha}_{\mathrm{F}}{ }^{2} \\
-2.02 \mathrm{~T}_{0} \\
-1.85\end{array}$} \\
\hline & & & & & 99 & 7.55032 & 7.55032 & $\begin{array}{l}-6.14 \text { To } \\
-13.06\end{array}$ & $\begin{array}{l}-6.14 \text { To } \\
-13.06\end{array}$ & $\begin{array}{c}-2.02 \mathrm{To} \\
-1.85\end{array}$ & \\
\hline 246 & 05/2011 & 1.06122 & 1.06122 & 90 & 90 & 7.55766 & 7.55766 & $\begin{array}{l}-6.05 \text { To } \\
-11.90\end{array}$ & $\begin{array}{l}-6.05 \text { To } \\
-11.90\end{array}$ & $\begin{array}{c}-2.02 \mathrm{To} \\
-1.72\end{array}$ & $\begin{array}{c}-2.02 \mathrm{To} \\
-1.72\end{array}$ \\
\hline 247 & $06 / 2012$ & 1.09223 & 1.09223 & 84 & 84 & 7.52368 & 7.52368 & $\begin{array}{c}-5.794 \mathrm{To} \\
-11.89\end{array}$ & $\begin{array}{c}-5.794 \mathrm{To} \\
-11.89\end{array}$ & $\begin{array}{c}-2.00 \mathrm{To} \\
-1.71\end{array}$ & $\begin{array}{c}-2.00 \mathrm{To} \\
-1.71\end{array}$ \\
\hline 248 & 01/2013 & 1.08635 & 1.08635 & 85 & 85 & 7.55766 & 7.55766 & $\begin{array}{c}-6.08 \mathrm{To} \\
-11.90\end{array}$ & $\begin{array}{c}-6.08 \mathrm{To} \\
-11.90\end{array}$ & $\begin{array}{c}-2.02 \text { To } \\
-1.72\end{array}$ & $\begin{array}{c}-2.02 \mathrm{To} \\
-1.72\end{array}$ \\
\hline 252 & $10 / 2014$ & 1.11179 & 1.111179 & 80 & 80 & 7.50922 & 7.50922 & $\begin{array}{c}-5.86 \text { To } \\
-12.01\end{array}$ & $\begin{array}{c}-5.86 \mathrm{To} \\
-12.01\end{array}$ & $\begin{array}{c}-2.02 \text { To } \\
-1.73\end{array}$ & $\begin{array}{c}-2.02 \mathrm{To} \\
-1.73\end{array}$ \\
\hline 253 & $03 / 2015$ & 1.11626 & 1.11626 & 80 & 80 & 7.50972 & 7.50972 & $\begin{array}{c}-5.60 \mathrm{To} \\
-11.96\end{array}$ & $\begin{array}{c}-5.60 \text { To } \\
-11.96\end{array}$ & $\begin{array}{c}-2.01 \text { To } \\
-1.72\end{array}$ & $\begin{array}{c}-2.01 \mathrm{To} \\
-1.72\end{array}$ \\
\hline 257 & 07/2016 & 1.12115 & 1.12115 & 81 & 81 & 7.50329 & 7.50329 & $\begin{array}{c}-5.70 \text { To } \\
-12.09\end{array}$ & $\begin{array}{c}-5.70 \mathrm{To} \\
-12.09\end{array}$ & $\begin{array}{c}-2.00 \mathrm{To} \\
-1.90\end{array}$ & $\begin{array}{c}-2.00 \mathrm{To} \\
-1.90\end{array}$ \\
\hline 259 & $04 / 2017$ & 1.13788 & 1.13788 & 83 & 83 & 7.52692 & 7.52692 & $\begin{array}{c}-5.69 \mathrm{To} \\
-11.82\end{array}$ & $\begin{array}{c}-5.69 \mathrm{To} \\
-11.82\end{array}$ & $\begin{array}{c}-1.71 \mathrm{To} \\
-1.99\end{array}$ & $\begin{array}{c}-1.71 \mathrm{To} \\
-1.99\end{array}$ \\
\hline
\end{tabular}

1 - Calculated using the old methodology

2 - Calculated using the new methodology

Source: Author

\section{CONCLUSIONS}

The algorithm of the five main codes applied in the methodology remained unchanged, only being transformed into subroutines of a main manager program. Due to this fact it was expected that Figures 6 and 7 presented complete data concordance, being an indicator of the reliability of the new methodology used. Tables 1,2, 3 and 4 reinforce this information, disassembling in detail to two different configurations, that the values are coincident until 
the last decimal place, while Table 5 compares overall over 7 years, to reinforce this information by taking at least one configuration studied per year.

The program was extensively discussed throughout the entire process with the IEA-R1 reactor operators so that it could best meet the needs of the operation team. Thismodification allows insertion of any number of fuel cross-sections into programs and removal of any limitation on changes in the input data provided by operators, who could change this data in any way they wish. Some bugs related to the interpretation of input files have also been removed over the years, and the program has been operating reliably for over seven years.This article is the completion of this project and the record of success in this process.

In the current phase, the project was evaluated by the quality department of the IEARl reactor, through comparisons, such as those provided by Table 5, recorded in internal technical reports of IPEN, demonstrating the applicability and reliability of the new methodology developed.

Using the old methodology, it takes about three hours to do all the calculations and entries in the assembly manuals. The use of the program manager this time was reduced to only five minutes of calculations, optimizing the time of the operators so that they can give priority to other tasks. In addition to providing the operator seek more configurations that suit the need, selecting the one that demonstrates the best performance.

\section{Acknowledgments}

This study had support and financing from FAPESP, in addition to the support of neutron and hydraulic calculators such as Dr. Valdemir Gutierrez Rodriguez and Mr. Mitsuo Yamaguchi. All the aforementioned support was essential for this new methodology to be applied and in current use. 


\section{REFERENCES}

BARHEN, J.; RHOTENSTEIN, W.; TAVIV,E., The HAMMER Code System Technion. Report: NP-565.Israel Institute of Technology, Haifa, Israel, 1978.

BARRY, R. F..LEOPARD - A spectrum dependent non-spatial depletion code. Report: WCAP-3269-26.Westinghouse Electric Corporation, USA, September 1963.

BENCIK, V.; FERENTIC, D.; DEBRECIN, N..Application of the coupled code RELAP5-QUABOX/CUBBOX in the system analysis of nuclear Power Plants. Kerntechnik, München, vol. 67, p. 252-255, 2002.

B00TH, T.E..Bad Estimates as a Function of Exceeding the MCNP Random Number Stride. Report: LA-UR-1423159.Los Alamos National Laboratory, USA, 2014.

BRASIL, Instituto de Pesquisas Energéticas e Nucleares(IPEN-CNEN/SP),Progress Report 2011-2013. 2014, São Paulo.

BRASIL. Reator IEA-R1. IPEN. Available in 〈www.ipen.br〉. Acess in 0cturber 6, 2017.

CÁRDENAS, J. P. N.. Monitoração contínua do balanço térmico para determinação da potência do reator IEA-Rl. 2000. Dissertação (Mestrado em Tecnologia Nuclear) -Instituto de Pesquisas Energéticas e Nucleares, São Paulo.

CHA0, J. COBRA-3C/RERTR - A Thermal-Hydraulic Subchannel Code with Low Pressure Capabilities. Computer Program. Suppliment-Argone National Laboratory. 1983.

DELP, D. L.; FISHER, D. L.; HARRIMAN, J. M.; STEDWELL, M. J..FLARE-A Three-Dimensional Boiling Water Reactor Simulator.General Electric Co. Atomic Power Equipment Dept., San Jose, Calif., USA, 1964.

DUNN,W.L.; SHULTIS,J.K.. Exploring Monte Carlo Methods. Elsevier Academic Press, Burlington, MA, 2011.

FOWLER, T. B.; VONDY, D. R.; CUNNIGHAM, G. W..Nuclear reactor core analysis code: CITATION. Report: ORNL-TM2496, Rev. 2, Suppl. 3.0ak Ridge National Laboratory, U.S.A., July 1972.

GREENMAN 6.; SMITH K.; HENRY A...Recent Advances in an analytic nodal method for static and transient reactor analysis. In: Proceedings of the Topical Meeting on Computational Methods in Nuclear Engineering: Hospitality House Motor Inn, Williamsburg, Virginia, April 23-25, 1979.

J00 H., BARBER D., JIANG G., DOWNAR T.. PARCS Purdue Advanved Core Simulator. In: PHYSOR 2002. Annals. Seoul, Korea, October 7-10, 2002.

LAMARSH, J. R.. Introduction to nuclear reactor theory. Second Edition. New York U.S.A.1972, 585 p.

LARANJ0, G. S., CONTI, CONTI, T. N., SANTOS, T. A. , FEDORENKO, G. G. , MAI0, M. F. , VINICIUS A. CASTRO. Implementation of the optimization for the methodology of the neutronic calculation and thermo-hydraulic in IEA-R1 Reactor. In: International Nuclear Atlantic Conference (INAC 2011)- Nuclear Energy New Jobs for a Better Life. Belo Horizonte. 2011.

LEPPÄNEN, J., PUSA, M., VIITANEN, T., VAltaVIRTA, V., KalTiaiSENAH0, T..The Serpent Monte Carlo code: Status, development and applications in 2013.Annals of Nuclear Energy, V.82, p. 142-150, 2015.

LITTLE, W. AND HARDIE, R. W. JR. 2DB user's manual - revision I. Report: BNWL-831, REVI.Battelle Pacific Northwest Laboratory, U.S.A., 1969.

MAIORIN0, J. R..The utilization and operational experience of IEA-Rl Brazilian Research Reactor. Report: IAEASM-360/7. Instituto de Pesquisas Energéticas e Nucleares. 1999. 
MAIORINO, J.R., STEFANI, G. L., MOREIRA, J. M. L., ROSSI, P. C. R., SANTOS, T. A..Feasibility to convert an advanced PWR from U02 to a mixed U/Th02 core - Part I: Parametric studies. Annals of Nuclear Energy. Vol.102, p. 47-55, 2017.

MONTEIR0 D. B. , STEFANI, G. L. , BUSSE, A. L., SANTOS, T. A. , SHIMOKAWA, J. 0. , RODRIGUES, C. S. , TERNG, N. , MOREIRA, J. M. L. , MAIORINO, J. R. , CARAJILESCOV, P.. 0 descomissionamento das plantas nucleares brasileiras.Estudos Avançados (USP. Impresso), Aceito para publicação, 2018.

STEFANI, G. L., THADEU DAS NEVES CONTI. Automatização dos parâmetros de segurança do reator IEA-R1.. REVISTA BRASILEIRA DE PESQUISA E DESENVOLVIMENT0.V.12, p.141-145, 2011.

STEFANI, G. L., CONTI, T. N.. Relatório Final de Atividades.FAPESP. Report: 2009/02992-5. 2010.

STEFANI, G. L., CONTI, T. N.. Relatório Parcial de Atividades.FAPESP.Report 2009/02992-5. 2010.

YAMAGUCHI, M..Descrição das Células do núcleo do Reator IEA-R1.Report $\mathrm{n}^{0}$ relt009r00, Projeto $\mathrm{n}^{0}$ PSI.REN.IEAR1.002. Instituto de Pesquisas Energéticas e Nucleares. 1997. 